\title{
2005 豪雪による人身雪害の発生状況調査
}

\section{Nationwide Survey of Personal Injury Cases Caused by 2005 Heavy Snowfall}

\author{
須 田 昌 則*1 •上村 靖 司*2 \\ Masanori Suda Seiji Kamimura
}

\section{1.はじめに}

中越地震後の雪による災害の軽隇を目的として発 足した「新潟県中越地震・雪水災害調查検討委員会」 は，冬季に入り雪害の発生が深刻化しつつあった 1 月10日，委員会ホームページ（以下 HP）上に, 「雪害の記録」ページを作成した"。広く情報を集 めることを目指して，HP 読者が自由に記入できる 仕組みをとったが，雪害の発生件数が予想をはるか に上回ったことから，系統立ててインターネット上 の情報を網羅的に集める必要に迫られた。

著者は当初，上記 $\mathrm{HP}$ への積極的な情報提供に関 与していたが, 雪害の発生範囲が, 地震被災地の新 潟県に留まらず，東北・北海道を含む全国となった ことから，2月12日に独立したblog（Weblog の 意味）サイト「雪害の記録 ‘04-05」を開設した ${ }^{2 !}$ 。

雪害に対する行政の対応を見ると, 新潟県は地震 の影響を踏まえ土木部を中心として, 降雪前から道 路状況や雪崩危険度に対するパトロールを強化して いた。2 名の死亡者が発生した 1 月26日の小千谷市 の旅館浴場屋根崩落事故の直後には，雪害に対する 防災体制を強化するとともに，地震により被害を受 けた家屋の雪害防止の徹底を関係各所に通知した。 事故 2 日後の 1 月28日には「雪害防止のため」と題 する知事談話がホームページを通じて配信され ${ }^{3}$, 雪崩パトロールの一層の強化や市町村，警察・消防， トラック協会の関連機関と連携した県の雪崩対策の 実施を表明した。

中越地域を中心に集中的な豪雪となった 2 月 1 日 には県豪雪警戒本部が設置され，2 月 2 日には首相 官㿟において小泉首相と麻生総務相が会談し, 新潟
県中越地震被災地で除雪作業などに支障が出ないよ う地元市町村と協議，対応するよう指示がだされた。 2 月 4 日から 8 日にかけては, 小千谷市, 川口町が, 仮設住宅の除排雪作業に自衛隊の災害派遣を要請し た。

2 月17日に県道松代高柳線（高柳町）で発生した 雪崩が発生。翌18日には雪崩現場下流で 1 名の死亡 が確認された。同日，同町高柳町の工事現場で雪崩 が発生し， 2 名が巻きこまれ，内 1 名死亡した。

新潟県は 2 件の雪崩死亡事故を受け，県豪雪対策 本部を設置し，「雪害に対する取り組みについて」 という知事のコメントを配信したい。

3月23日，消防庁から「今冬の雪による被害状況 等 (第 4 報)」が発表され ${ }^{5}$ ，全国の雪による死亡 者数は86名と報告されたが，著者がインターネット ニュース記事を収集・分析した死亡者数よりも明ら かに少なかった。

一般に，重大事故は翌朝の新聞を待たずして，イ ンターネットニュースサイトで速やかに報じられる。 発生から揭載までの時間は，早くて数時問，遅くと も同日夜には記事として揭載される。雪害による死 亡事故も例外ではなかった。

本調查は，インターネットで配信されているニュー 又記事を情報源とし，記事の収集・整理・分析によっ て，2005豪雪における人身雪害の状況を総括すると ともに，インターネットの情報配信技術を利用した リアルタイム雪害調查手法の可能性を検証する。

\section{2. 死亡者数調查}

本報が対象とする人身雪害は，日常生活の中で直

* 1 新潟県中越地震・雪氷災害調査検討委員会 生活関連 WG 雪害記録担当, 東北丸山株式会社

*2 長岡技術科学大学 機械系 
面する様々な活動（生活活動，社会活動，産業活動） の中で起こる事故・災害のみとする。例えば，山岳 地带でスノーボードビデオ撮影中のスタッフが 1 名 雪崩に巻きこまれ死亡したが，一般的な市民の生活 活動とはか漓倠えているので本調査には含まない。 また，交通事故については，道路管理の観点から論 ずるべきであり、ここでは除く。

調查方法は，次の通りである。

(1) インターネット上の総合ニュースサイトは，660 を越える小さいニュースサイト（例：毎日新聞や 朝日新聞）の記事を集約している。そ㣗ら記事は, RSS (Rich Site Summary, ウェブサイトの記 事の見出しゃ概要を配信するためのXML 技術) と呼ばれる最新のIT 技術によって, 専用ソフト ウエアで容易に巡回閲覧できるようになっている。 ニュース記事の更新時間は, 総合ニュースサイト で異なるが，お㧍むね15分と頻繁に更新される。 記事によっては，短時間で消えてゆくこともある ため,ソフトウェアによって自動的に収集し記録 するように，所定のニュースサイトへとリンクを 張っておく。

(2) 総合ニュースサイトごとに契約しているニュー スソースが異なるので，記事収集精度を上げるた めに 5 社 (Google, Yahoo, LiveDoor, Excite, goo）を選択した。その他, 北海道, 東北, 関東 甲信越地方の地方テレビ局のサイトも全て調査対 象としたが，それらの大半がR S S に非対応であっ たことから，手作業にて巡回調査した。

(3) 検索の基本キーワードを表 1 に示す。基本ワー ドのみの検索では，膨大な数のニュース記事がヒッ トし事後処理に時問がかかるため, 基本キーワー ドをいくつか組み合わせて検索を行った。その組

表 1 検索の基本ワードー覧

\begin{tabular}{|l|l|l|l|}
\hline \multicolumn{1}{|c|}{ 気 象 } & \multicolumn{1}{|c|}{ 地 名 } & \multicolumn{1}{|c|}{ 災 害 } & \multicolumn{1}{|c|}{ 交 通 } \\
\hline 雪 & 新潟 & 死亡 & 通行止 \\
\hline 皮 & 中越 & 死傷者 & 運休 \\
\hline 凍結 & 小千谷 & 重軽傷 & 代替 \\
\hline 雪崩 & 川口 & 聜息 & 渋滞 \\
\hline 融雪 & 長岡 & 凍死 & 则ッ $7^{\circ}$ \\
\hline 土砂崩れ & 山古志 & 事故 & 閉鎖 \\
\hline 雨水 & 十日町 & 凍結 & \\
\hline
\end{tabular}

み合わせについては，試行錯誤の段階であり，必 ずしも統一されたルールはまだない。

(4) 抽出されたニュース記事は，多数の重複を含む ため, 選別と集約の作業が不可欠である。この作 業の自動化はまだであり，今回は手作業で行った。 (5) 調查期間は，2004年12月 1 日〜2005年 3 月18日 とした。

\section{3 . 調査結果}

雪害による死亡者は，14県にまたがり，その総数 は2005年 3 月18日時点で 103 人となった。

消防庁の内訳86名と異なるのは，日常生活で直面 する様々な生活活動で起こる事故, 災害を対象とし て, 記事の内容から主たる死亡要因を判断したこと による。例えば，览童が遊んでいる最中に湖やプー ルに転落するといつた事故や，除雪作業中に鉄道線 路敷地に侵入し列車に䡕かれるといった複合的な原 因で発生した事故も，ここでは統計に加えている。

\section{1. 県別の死亡者数}

図 1 に県別の死亡者数を示す。横軸は県であり， 各県の 4 本の棒は左から順に 12 月から 3 月の月別死 亡者数を表す。グラフ上の数字は娊毎の合計である。 図を見ると，新潟県が30人と一番多く，ついで北 海道 21 人, 青森 14 人, 山形 13 人, 秋田 9 人と続く。 グラフ中では示していないが新潟県の事故の大半は, 昨年発生した水害や地震の被災地域で発生している。

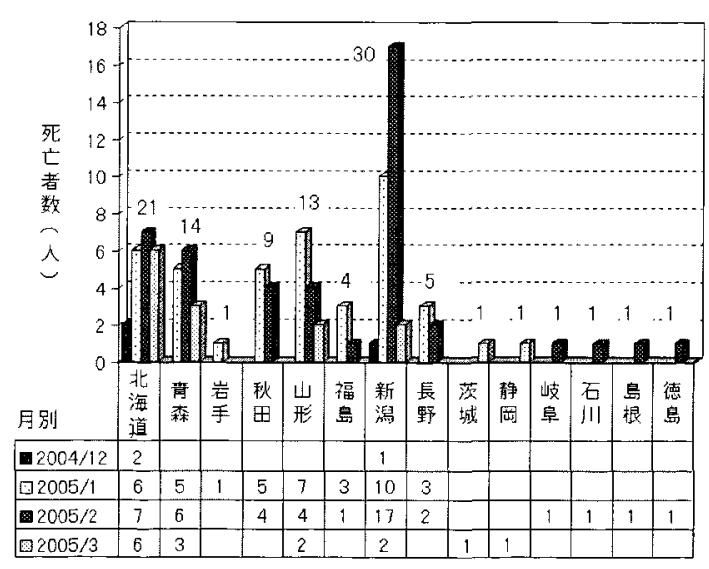

図 12005 豪雪における県別，月別の死者数 


\section{2. 発生人数の推移}

図 2 に日每の死亡者数の推移, 図 3 は代表地点 （札幌・青森・米沢・長岡）の AMeDAS 積雪媣で ある。両図を比較すると，急激な積雪深の増加，あ るいはその数日後に, 死亡者数肪増加していること がわかる。

特に長岡で集中的な豪雪となった 2 月初めには, 各地で屋根からの転落や落雪による死亡事故が相次 いだ。1月中旬に死亡者が多いのは，東北地方が豪 雪に見舞われたことと対応する。

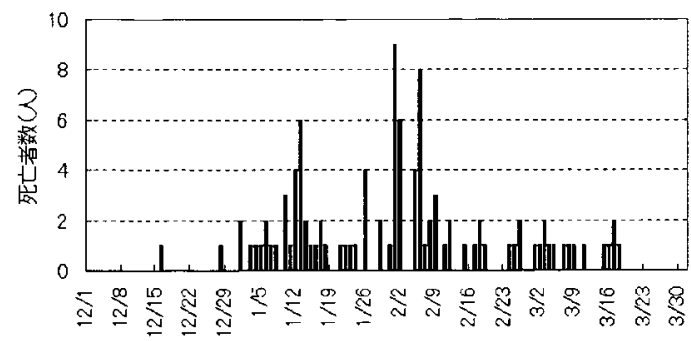

図 2 日死亡者数
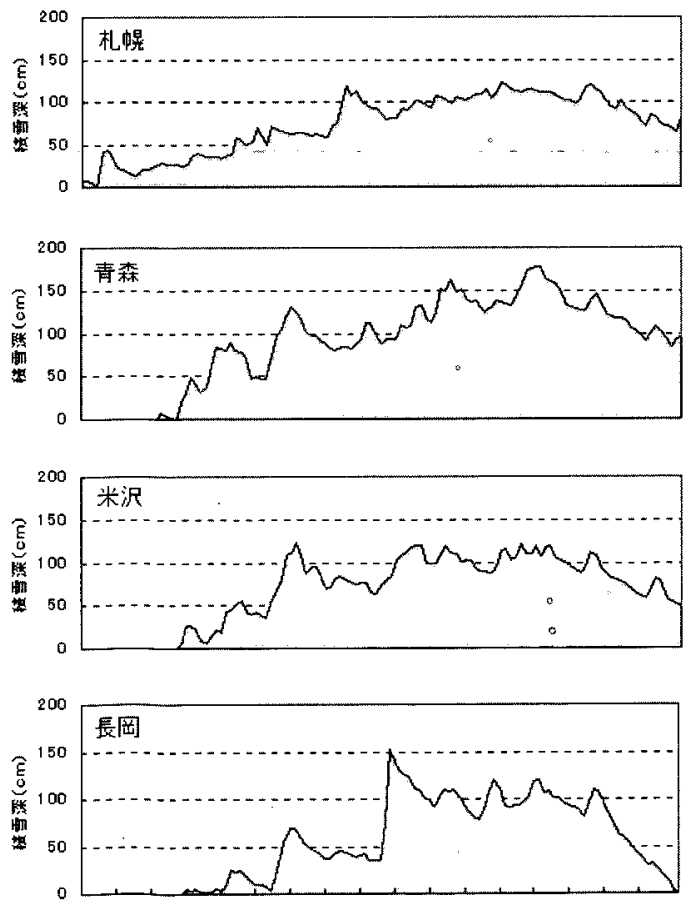

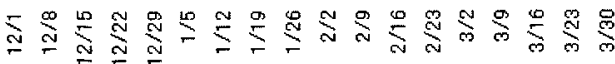

図 3 アメダス積雪深

\section{3. 死因別の死亡者数}

死因別に区分すると（図 4), 屋根からの転落死 が32人，落雪による死死・空息死が 26 人，水路等な ど水への転落死が 15 人と続いた。

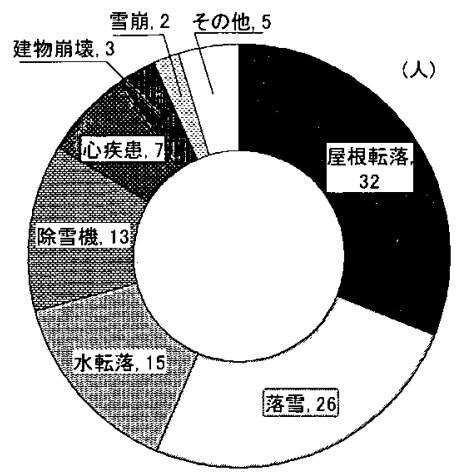

図 4 死因別内訳

屋根からの落下による事故を個別に見ると，その 多くは命綱をしていなかった。落下地点に雪がある かないか，堆雪が多いか少ないかで死因は分かれた。 つまり落下地点が無雪であると外傷性疾患による死 亡となり，雪はあるが堆雪が多すぎると雪に埋まり 窒息による死亡となった。反面，積雪によって助かつ たケースも少なくない。

2 月以降，相対的に落雪事故の割合が増えた。特 に雪庇処理作業中に屋根雪が崩落する事故が目立つ た。

屋根や梯子などの高所での除雪作業中の事故が注 目されやすいが, 屋根以外の家屋周辺の除雪作業中 にも少なくない数の死亡事故が発生していることも 明らかになった。用水路への投雪作業中，水路上に 覆いかぶさった雪庇を踏み抜き転落し，流され死亡 するという事故も発生した。市街地の流雪溝は安全 のための蓋が設置され，投雪作業時以外は蓋を閉じ るよう指導されているが，地方の用水路は蓋もなく， 場所によっては柵も設置されていないため，場合に よっては屋根以上に危険であるということがいえる。 除雪機や重機による死亡事故も13人と多かった。重 軽傷者まで含めると数が非常に多い。除雪作業中に, エンジンをかけたままロータリー部に固着した雪を 取り除こうとして，頭や腕を巻きこむケースが多い。 また除雪機のそばで子供が雪遊びをしたり，他の作， 
業者がいて，それに気がつかず巻き込んだり，屋根 から転落した先にたまたま除雪機があったという悲 惨な事故も起こっている。そしてその被害者の大半 が，加害者の家族や親類であった。

全体的に言えることだが，雪下ろし作業を一人で 行って事故に遭うケースが压倒的に多かった。家族 や知人による「いなくて探したら見つかった」とい うコメントが目立った。心疾患も 7 人と多く, 雪処 理は高齢者にとって重労働であることは言うまでも ないが，これらの事故も早期発見で防げた可能性の 高いものである。

家屋倒壊に伴う人身事故は, 新潟と青森で発生し, 3名がそれに巻き込まれて死亡した。雪崩によって 新潟で 2 名が死亡した。その他，新潟で自動車の排 気管が雪で塞がっていることを知らずに暖機運転を 継続し, 除雪作業終了後にそのまま乗車してしまい,

一酸化炭素中毒で搬送先の病院で死亡した事故もあっ た。”

青森では家の雪を，線路をまたいで畑に捨てに行 く途中列車に轁加犯死亡するといった，複合的な原 因による事故も発生した。また父親が車の雪下ろし をするためバックさせた際に，死角にいた 2 歳の娘 を輈いて死亡させるという事故も起きている7”。

\section{4. 年齢別の死亡者数}

年齢別に並べ替える (図 5 参照) と，60歳以上が 78 人と 8 割弱を占めた。その一方で，今冬は子供に よる事故も相次いだ。その多くが水への転落と除雪 機による事故であった。

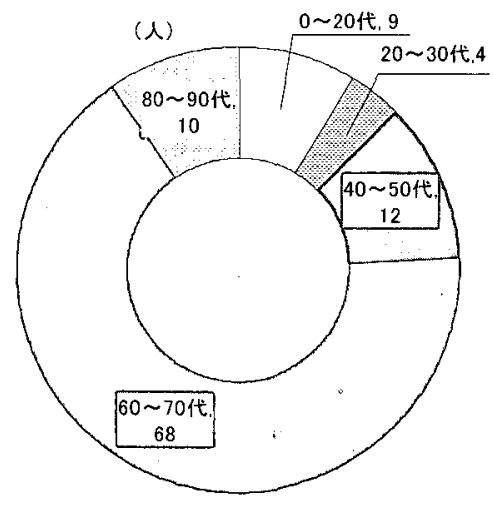

図 5 年齡別死亡者数

\section{4 、世界の雪害}

表 1 に示した基本キーワードに相当する英単語を 適用すれば，海外の雪害発生状況の調查も可能であ る。公的にはアジア防災センターが中央アジアで発 生した災害を報告している ${ }^{8)}$ 。また報道機関としては Reuters AlertNet Foundation (ロイター社) が 各報道機関を通して入手した現地踏查結果を報告し ている9。今冬に発生した世界の霊害を表 2 に示す。

特に中央アジアで大規模な雪崩や豪雪などで 1000 人以上の死亡者が出ていた。インドでは大規模な雪 崩によって道路が数週間寸断されたため，孤立地域 が多数発生し救出作業を遅れたため，被害を大きく した。救出作業に当たっては，住民が素手で雪をか き分けたという記述もあった。こういつた地域は， 内戦や紛争地帯ということもあり，雪対策が十分な 地域のほうがむしろ少ないのかもしれない。

表 2 アジアを中心として発生した世界の雪害

\begin{tabular}{|c|c|c|c|}
\hline 日付 & 地域名 & 災害名 & 被害状況 \\
\hline $05 / 02 / 05$ & タジキスタン & 雪崩 & 12 人死傷 \\
\hline \multirow[t]{3}{*}{$05 / 02 / 11$} & パキスタン & 洪水 & 600 人死亡 \\
\hline & & 豪雪 & 700 人重軽傷 \\
\hline & & 寒波 & \\
\hline \multirow[t]{2}{*}{ 05/02/19 } & インド & 豪雪 & 323死亡 \\
\hline & カシミール & 雪崩 & 5000家屋倒壊 \\
\hline \multirow[t]{2}{*}{$05 / 02 / 22$} & アフガニスタン & 豪雪 & 子供 180 人を含む \\
\hline & & 寒波 & 260 人死亡 \\
\hline $05 / 02 / 24$ & 欧州・米 & 寒波 & 全域交通障害 \\
\hline $05 / 02 / 27$ & チベット & 豪雪 & 17000家畜被害 \\
\hline \multirow[t]{2}{*}{ 05/03/02 } & アフガニスタン & 融雪 & 3人死亡 \\
\hline & & 洪水 & 300家屋倒壊 \\
\hline \multirow[t]{4}{*}{ 05/03/01 } & イギリス & 雪玉 & 10歳子供 \\
\hline & & (Snow & 農場で500kg の \\
\hline & & Ball) & 雪玉が転がって \\
\hline & & & きて直撃 \\
\hline \multirow[t]{3}{*}{$05 / 03 / 10$} & 中国雲南省 & 豪雪 & 8名死亡 \\
\hline & & 風雨 & 90万人影響 \\
\hline & & & 3000ha 農地被害 \\
\hline $05 / 03 / 16$ & オーストリア & 雪崩 & 32 人死亡 \\
\hline \multirow[t]{2}{*}{$05 / 03 / 22$} & アフガ二スタン & 融雪 & 200 人以上死亡 \\
\hline & & 洪水 & \\
\hline
\end{tabular}




\section{5. 考察}

今冬の人身雪害を見ると, 60 墄以上の高齢者の死 亡者が多かった。そのうち屋根からの転落による死 因が 30 人と高齢者事故の 4 割を占めた。自動車を運 転するときにシートベルト着用が義務づけられてい るように，屋根に登っての雪下ろし時は命綱を着用 しなければならない。またその命綱が容易に取り付 け可能な屋根設備が必要である。

落雪による死亡者も 10 人と $13 \%$ を占めた。屋根の 雪庇処理作業中の事故も多い。憶測の域を出ないが, 体力的には雪下ろしが出来ないが, せめて雪庇処理 くらいは自分で，と考えたかもしれない。

地域性を見ると, 死亡者は北海道から鳥取, 徳島 と非常に広域的に分布した。今冬の豪雪の広域性と 深刻さを反映している。

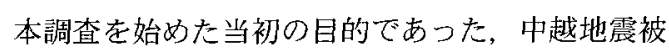
災地域における死亡者は, 20 人と全体の 2 割を占め た。このうち地震の影響があったと考えられる事故 は，建物屋根崩落による 2 名と雪崩（2月17日）と， 報道記事からは読み取れる。被災地域には，本委員 会が発行した雪災害防止の注意喚起のためのパンフ レットが全戸に配布されている。マスコミにも注目 され繰り返し報道されたこと,そして新潟県による 除雪ボランティアの募集などの公的支援もあり，雪 害防止策はある程度の水準で保証されたと思われた が，実際に冬を迎えて見るとボランティアの雪下ろ し作業に対する規制が多く満足に活動できない状況 であった。そしてボランティア投入の地域間格差を 生みだし、住民から不満の声が噴出すると同時に,

行政担当者も対応に追われる事態となった。

政府の中央防災会議は，3月7日に豪雪対策の通 知を出し, 関連省庁や都道府県に人身事故の防止対 策の徹底を指示した。しかし発令した時は，既に全 体の93\%の96人が死亡した後である。

雪害は広域かつ集中的に発生し，様々な被害をも たらす。1日，もしくは 1 時間という時間単位で情 報を収集し的確な指示を促す行政の資料作成のため に，本報で提案した調查手法を応用すれば，安优で 効率的なシステムが実現できると考えている。

インターネットを通じて誰もが容易に検索できる
システムを実現すれば，例えば教職員や社会福祉協 議会担当者, ホームヘルパーなど地域に密着して働 く人たちが, 地域住民, 特に子供や高齢者に注意を 促すことが可能となる。本手法の適用を雪害に限定 する必要はなく，検索の基本ワードを変更すれば地 震や火山噴火，津波などの災害二ュースを収集して 整理することも容易に行える。

本手法は, 既存の検索機能, 情報抽出, ウェブロ グ入力を繋ぐことだけで自動収集・分析・整理・発 信のプロセスを実現できる可能性を秘めている。事 故や災害の軽減に対して価值ある情報がリアルタイ ムで効率よく発信できるということを今冬の調查で 実証したと考えている。

\section{6. まとめ}

新潟県中越地震・雪水災害調查検討委員会の活動 の一環として始まった「雪害の記録」は，2005豪雪 を広域的にかつ網羅的に調查する新たな情報収集・ 分析・整理・発信の新しい手法を生み出し，その効 果が奏証された。そのアクセス数の多さから, 社会 的関心の高さをうかがい知ることができた。一方で, 「雪害が災害扱いされていない」「広域的に網羅さ れた情報として広く集められ配信されていない」， という問題点も明らかになった。

世界に目を向けたとき，雪害対策先進国である日 本に比へ，特に中東で深刻な状況にあることがわか り，国際的な情報共有と連携が必要であることも緊 急の課題として浮き彫りとなった。

本報告で提案した手法は，低いコストで高い効果 を生むことが明らかとなったことから，手法のさら なる改善をしながら，継続的に調査・発信を続ける 予定である。

\section{謝辞}

本速報を作成するに当たり、新潟県中越地震・雪 水災害調查検討委員会のメンバーの方、特に生活関 連WGの皆様に、最後にブログサイト「筜害の記録 ’04-05」の発案を下さった皆様に感謝の意を表しま す。 


\section{参考文献}

1）新潟県中越地震雪氷災害調査検討委員会, “中 越地震後の雪水災害の軽隇のために”, 雪害の 記録，http://snowy.web.infoseek.co.jp/winter_eq/

2）須田昌則 : 雪害の記録 ’04-05 http://blog.goo.ne.jp/chikibosai/

3 ）新潟県知事, 雪害防止のために, http://www. pref.niigata.jp/content/jishin/minasamahe2.html, 2005.1.

4）新潟県土木部, 平成16年度豪雪による被害と対 応, http://bosai.pref.niigata.jp/content/gosetsu /sokuhou/gousetsu_pamphlet.pdf, 2005.3
5 ）総務省消防庁：今冬（平成16年12月以降）の雪 による被害状況等（第 4 報），2005.3

6 ）新潟県融雪災害警戒本部：今冬の雪による被害 （人的）状況, 2005.5

7) 青森県総務部防災消防課：今冬の豪雪による被 害, 2005.4

8 ）アジア防災センター（ADRC） http://www.adrc.or.jp/top_j.php

9) Reuters AlertNet Foundation http://www.alertnet.org/ 